\title{
In Vitro Anthelmintic Activity of Ethanol Stem Bark Extract of Albizia ferruginea (Guill. \& Perr.) Benth
}

\author{
Miriam Tagoe, Yaw Duah Boakye (D), Theresah Appiah Agana, Vivian Etsiapa Boamah, \\ and Christian Agyare
}

\begin{abstract}
Department of Pharmaceutics, Faculty of Pharmacy and Pharmaceutical Sciences, Kwame Nkrumah University of Science and Technology, Kumasi, Ghana
\end{abstract}

Correspondence should be addressed to Yaw Duah Boakye; ydboakye.pharm@knust.edu.gh

Received 23 December 2020; Revised 14 April 2021; Accepted 16 April 2021; Published 28 April 2021

Academic Editor: José F. Silveira

Copyright (C) 2021 Miriam Tagoe et al. This is an open access article distributed under the Creative Commons Attribution License, which permits unrestricted use, distribution, and reproduction in any medium, provided the original work is properly cited.

\begin{abstract}
Albizia ferruginea (Guill. \& Perr.) Benth bark is used in the traditional medicine as a vermifuge. This study sought to determine the anthelmintic activity of the stem bark extract of Albizia ferruginea. The powdered A. ferruginea stem bark was extracted with ethanol. Phytochemical screening was carried out on A. ferruginea ethanol extract (AFE) and then screened for its anthelmintic property against Pheretima posthuma and Haemonchus contortus using the adult motility assay. The effect of AFE and its fractions on the anthelminthic activity of mebendazole and albendazole were also determined using the adult worm ( $P$. posthuma) motility assay. AFE showed a dose-dependent anthelmintic activity against $P$. posthuma and $H$. contortus. The least concentration of AFE $(0.5 \mathrm{mg} / \mathrm{mL})$ paralyzed and killed $P$. posthuma within $272.50 \pm 12.42 \mathrm{~min}$ and $354.50 \pm 5.06 \mathrm{~min}$ of exposure, respectively. AFE at the least test concentration $(0.14 \mathrm{mg} / \mathrm{mL})$ caused paralysis and induced death of $H$. contortus, after at $63.50 \pm 2.98$ and $254.96 \pm 2.44 \mathrm{~min}$ of exposure, respectively. AFE extract at 0.25 and $0.125 \mathrm{mg} / \mathrm{mL}$ increased the paralytic and helminthicidal activities of albendazole. The paralytic and helminthicidal activities of mebendazole were reduced when combined with AFE $(0.25$ and $0.125 \mathrm{mg} / \mathrm{mL})$. Among the three fractions obtained from AFE, the methanol fraction showed the highest anthelmintic activity. The methanol fraction at $0.5 \mathrm{mg} / \mathrm{mL}$ caused paralysis after $69.90 \pm 0.15 \mathrm{~min}$ and death of worm after $92.53 \pm 0.74 \mathrm{~min}$ of exposure. The petroleum ether and ethyl acetate fractions showed relatively low anthelmintic activity. Phytochemical screening of AFE revealed the presence of tannins, saponins, glycosides, alkaloids, and coumarins. The results from this study show that $A$. ferruginea possesses anthelmintic activity which gives credence to its folkloric use.
\end{abstract}

\section{Introduction}

Helminthiasis occurs when there is an infestation of part of the body with worms. These worms are normally found in the digestive tract but may also burrow into the liver and sometimes other organs [1]. Helminthiasis occurs worldwide, especially in tropical and subtropical countries where poverty is high [2]. The World Health Organization reports that over 1.5 billion people are infected with one or more soil-transmitted helminths, notably, hookworm, Trichuris trichiura, and Ascaris lumbricoides [3]. Approximately, a quarter of the total population in Sub-Saharan Africa is infected with one or more helminths [4] with most West African countries having a prevalence greater than 70\% [5]. Nematodes are the most common among all helminths [4].
In areas where prevalence is high, one can be infected simultaneously with more than one type of helminth [6]. The neglected tropical diseases, of which helminth infections form a part, cause about 534,000 deaths every year and a disease burden of 57 million disability-adjusted life-years (DALYs) [7]. Intestinal worms such as Haemonchus contortus have been found to have developed resistance to some anthelmintics, namely, levamisole, albendazole, and closantel [8]. Apart from the development of anthelmintic resistance $[9,10]$, most of the drugs used to treat these worm possess some common side effects such as nausea, vomiting, abdominal pain, and fall in blood pressure in humans [11], and in livestock, coupled with the fact that many farmers in the developing countries are not able to afford synthetic anthelmintics to control the spread [12]. Again, the issue of 
anthelmintic resistance in humans has become a matter of concern due to the evidence of resistance in livestock [13], thus posing a serious threat to the production of livestock in developing countries. Therefore, there is the need to develop other alternatives for control of helminth infestations [14]. Medicinal plants are among the natural products being explored for their anthelmintic properties [12, 15-17].

Albizia ferruginea (Guill. \& Perr.) Benth belongs to the family Fabaceae. It is usually found in woodland, lowland rainforest, and scrub vegetation. It is a perennial medicinal plant widely used in Africa [18]. The bark of $A$. ferruginea is used in traditional medicine to treat dysentery, bronchial infections, and pain caused by fever. In central Cameroon, inhabitants use leaves maceration as a purgative in children to treat intestinal disorders [19]. Secondary metabolites such as flavonoids [20], terpenoids, saponins, sterols, and tannins have been identified in Albizia species [18]. Although $A$. ferruginea has been reported for its antioxidant [21], antiinflammatory [22], and antimicrobial activities [18], very little research have been carried out on its anthelminthic activities. The stem bark of $A$. ferruginea may have a promising anthelmintic activity due to its traditional usage as a purgative and a vermifuge [23]. This study, therefore, evaluated Albizia ferruginea for its anthelmintic properties.

\section{Materials and Methods}

2.1. Collection of Stem Bark of A. ferruginea. The stem bark of A. ferruginea was collected from Kwahu Asasraka (6.627092,-0.692874) in the Eastern Region of Ghana in January 2018. The plant material was identified and authenticated by Dr. George Henry Sam, a lecturer at the Department of Herbal Medicine, Faculty of Pharmacy and Pharmaceutical Sciences, KNUST, Kumasi, Ghana. A voucher specimen with the number KNUST/HMI/2018/SB007 has been kept at the herbarium of the Department of Herbal Medicine, KNUST. The sample was dried in shade for seven days to obtain uniform dry weight. Ten kilograms of the dried sample was then milled and stored at $25^{\circ} \mathrm{C}$ in glass containers for further investigations.

2.2. Preparation of Ethanol Extract of A. ferruginea. Powdered plant material $(150 \mathrm{~g})$ of $A$. ferruginea bark was weighed and suspended in $1600 \mathrm{~mL}$ of ethanol (UK Chemicals, Kumasi, Ghana) and shaken intermittently for 3 days at room temperature. The suspension was then filtered using Whatman filter paper number 1 (Sigma-Aldrich, London, $\mathrm{UK})$, and the filtrate was concentrated using a rotary evaporator (Genser Scientific Instruments, Germany) at $40^{\circ} \mathrm{C}$ under reduced pressure. The extract was kept at $4^{\circ} \mathrm{C}$ in the refrigerator until needed. The ethanol stem bark extract of A. ferruginea was coded as AFE, and its percentage yield was calculated to be $9.8 \% \mathrm{w} / \mathrm{w}$.

2.3. Phytochemical Screening. Phytochemical screening of ethanol extract of $A$. ferruginea was carried out to detect the presence or otherwise of secondary metabolites such as tannins, alkaloids, and flavonoids, following standard procedures [24, 25].
2.4. Fractionation of AFE Extract Using Column Chromatography. Silica gel (70 to 230 mesh, Sigma-Aldrich, London, UK) was used as the stationary phase. Fifteen (15.0) grams of blank silica was packed into a dried glass column $(50 \mathrm{~mm} \times 42 \mathrm{~cm}$ ) (Fisher Scientific GmbH, Schwerte, Germany). Afterwards, $136 \mathrm{~g}$ of the AFE was reconstituted in $25 \mathrm{~mL}$ of $70 \%$ ethanol and adsorbed unto $10 \mathrm{~g}$ of silica gel. The slurry obtained was dried thoroughly at room temperature. The mixture obtained was then loaded on top of a previously packed blank silica within the column. The mobile phases, petroleum ether, ethyl acetate and methanol (UK Chemicals, Kumasi, Ghana), were used. Elution began with absolute petroleum ether, and when the eluate was colourless, ethyl acetate was used followed by methanol. The fractions were collected and bulked according to their TLC profiles [26].

2.5. Test Organisms. Pheretima posthuma commonly known as adult Indian earthworms have an anatomical and physiological semblance to the human intestinal roundworms Ascaris lumbricoides [27]. Adult P. posthuma (earthworms) were collected from the Wiwi River, behind the Department of Theoretical and Applied Biology, College of Science, Kwame Nkrumah University of Science and Technology (KNUST), Kumasi, Ghana. The earthworms were washed with Ringer's lactate solution to remove soil debris.

Haemonchus contortus is a highly pathogenic parasite of small ruminants [28]. This worm feeds on the blood of ruminants and grows well in warm temperate, tropical, and subtropical regions [29]. Haemonchus contortus worms were collected from the intestines of slaughtered cows at the Tamale Abattoir, Northern Region of Ghana, with the help of the Veterinary Officers and kept in Ringer's lactate solution for transportation. The length of $P$. posthuma and $H$. contortus measured were within the ranges of 5.0 to $7.0 \mathrm{~cm}$, and 4.0 to $6.0 \mathrm{~cm}$, respectively.

2.6. Determination of Anthelmintic Activities. The anthelmintic activity against $P$. posthuma was determined using the adult motility assay described by Chander et al. [17]. Nine concentrations $(32,16,8,4,2,1,0.5,0.25$, and $0.125 \mathrm{mg} / \mathrm{mL})$ of AFE and its fractions (methanol, ethyl acetate, and petroleum ether) were prepared. Adult earthworms 5 to $7 \mathrm{~cm}$ in length ( $P$. posthuma) were aseptically transferred into appropriately labelled petri dishes (Fisher Scientific $\mathrm{GmbH}$, Schwerte, Germany) containing different concentrations of AFE and AFP. The worms were then observed over a maximum of $8 \mathrm{~h}$ for paralysis and death. Paralysis was said to occur when no movement of any part was observed except when the worms were vigorously shaken. Death was ascertained when the worms neither moved when shaken vigorously nor revived when placed in Ringer's lactate solution (B. Braun Medical Ltd., UK) and sometimes followed by fading away of their body colour. The positive control group was placed in petri dishes containing albendazole (SigmaAldrich, London, UK) $(10,5,2.5,1.25$, and $0.625 \mathrm{mg} / \mathrm{mL})$. Three (3) worms of about the same size per petri dish were used. They were observed for their motility and the time 
taken for paralysis and death of worms. The above procedure was carried out in triplicates.

For $H$. contortus, its anthelmintic activity was conducted using the adult motility assay described by Jabbar et al. [12]. Mature live $H$. contortus worms were washed in Ringer's lactate solution. Seven groups consisting of three worms each were used for this assay. The worms in the various groups were exposed to the following treatments, respectively: 0.57 , $0.285,0.14,0.07$, and $0.035 \mathrm{mg} / \mathrm{mL}$ of AFE, $0.5 \mathrm{mg} / \mathrm{mL}$ albendazole (positive control), and Ringer's lactate (negative control). The worms were observed over an $8 \mathrm{~h}$ period for paralysis and death. Paralysis was said to occur when no movement of any part was observed except when the worms were vigorously shaken. Death was ascertained when the worms neither moved when shaken vigorously nor revived when placed in Ringers lactate solution and sometimes followed by fading away of their body colour.

2.7. Determination of Resistance Modifying Activity of AFE Extract against $P$. posthuma. The effect of the ethanol extract of A. ferruginea on the activity of albendazole (SigmaAldrich, London, UK) against $P$. posthuma worms was determined. Two subactivity concentrations of the AFE extract $(0.25$ and $0.125 \mathrm{mg} / \mathrm{mL})$ and $10 \mathrm{mg} / \mathrm{mL}$ stock solution of albendazole were used. The albendazole stock solution was serially diluted to obtain the following concentrations: 5 , $2.5,1.25$, and $0.625 \mathrm{mg} / \mathrm{mL}$. A volume of $50 \mathrm{~mL}$ of each concentration was transferred into appropriately labelled petri dishes (three petri dishes per concentration). Three adult $P$. posthuma worms of lengths ranging between 5 and $7 \mathrm{~cm}$ were placed into each of the labelled petri dishes filled with the respective concentrations of albendazole. The set up was observed for 8 hours for the time of paralysis and death. The procedure was performed in triplicates. The above procedure was repeated using mebendazole (Sigma-Aldrich, London, UK) [30].

2.8. Statistical Analysis. Data were analysed with GraphPad Prism version 8.0 for Windows (Graph Pad Software Inc., San Diego, CA, USA). One-way ANOVA followed by Dunnett's post hoc test was used to analyse data obtained for anthelmintic studies.

\section{Results}

3.1. Phytochemical Screening of AFE Extract. Phytochemical screening was conducted to determine the probable phytochemicals in AFE. Phytochemical screening of the AFE revealed that tannins, saponins, glycosides, alkaloids, and coumarins were present but flavonoids were absent (Table 1).

3.2. Determination of Anthelmintic Assay Using P. posthuma. At the highest concentration of $32 \mathrm{mg} / \mathrm{mL}$, AFE paralyzed and killed all worms within $5.67 \pm 0.67$ and $8.82 \pm 0.82 \mathrm{~min}$ of exposure, respectively. At the least concentration of $0.5 \mathrm{mg} / \mathrm{mL}$, AFE paralyzed and killed all worms within $272.50 \pm 12.42 \mathrm{~min}$ and $354.50 \pm 5.06 \mathrm{~min}$ of exposure, respectively (Figure 1(a)). Albendazole $(10 \mathrm{mg} / \mathrm{mL}$ ) paralyzed worms within $130.72 \pm 1.50 \mathrm{~min}$ and killed the worms within $232.15 \pm 1.29 \mathrm{~min}$ of exposure. At $1.25 \mathrm{mg} / \mathrm{mL}$, alben-
TABle 1: Phytochemical screening of AFE.

\begin{tabular}{lc}
\hline Secondary metabolites & AFE \\
\hline Tannins & + \\
Saponins & + \\
Glycosides & + \\
Alkaloids & + \\
Flavanoids & - \\
Coumarins & + \\
\hline
\end{tabular}

+: the presence of secondary metabolite; -: absence of secondary metabolite.

dazole paralyzed and killed worms within $330.60 \pm 9.47 \mathrm{~min}$ and $389.16 \pm 7.06 \mathrm{~min}$ of exposure, respectively (Figure 1(b)).

3.3. Determination of Anthelmintic Assay Using H. contortus. AFE showed a dose-dependent activity against $H$. contortus. At concentrations of $0.14,0.285$, and $0.57 \mathrm{mg} / \mathrm{mL}$, AFE significantly ( $p$ value $<0.0001$ ) caused paralysis of worms at $63.50 \pm 2.98,55.75 \pm 1.41$, and $46.93 \pm 0.85 \mathrm{~min}$, respectively, compared to the negative control (Ringer's lactate solution) which showed no paralysis after the maximum time $(8 \mathrm{~h})$ of exposure (Figure 2(a)). Concentrations of AFE at $0.14,0.285$, and $0.57 \mathrm{mg} / \mathrm{mL}$ significantly ( $p$ value $<0.0001$ ) caused death of worms at $254.96 \pm 2.44 \mathrm{~min}, 236.979 \pm$ $2.272 \mathrm{~min}$, and $177.933 \pm 1.929 \mathrm{~min}$ of exposure, respectively (Figure 2(b)), and this was significant $(p<0.0001)$ when compared with the negative control group. Albendazole $(0.5 \mathrm{mg} / \mathrm{mL})$ caused paralysis and death of the worms at $75.26 \pm 2.00$ and $258.09 \pm 2.84 \mathrm{~min}$ of exposure, respectively (Figure 2).

3.4. Influence of AFE Extract on Anthelmintic Activity of Albendazole. Albendazole alone at $10 \mathrm{mg} / \mathrm{mL}$ paralyzed all worms after $130.721 \pm 1.499 \mathrm{~min}$ of exposure. AFE $(0.25 \mathrm{mg} / \mathrm{mL})$ combined with $10 \mathrm{mg} / \mathrm{mL}$ albendazole significantly $(p<0.001)$ reduced the paralysis time. When $10 \mathrm{mg} / \mathrm{mL}$ albendazole was combined with $0.25 \mathrm{mg} / \mathrm{mL}$ AFE, the worms were paralyzed after $72.296 \pm 0.777 \mathrm{~min}$ of exposure. Similar effects were observed at lower concentrations of albendazole $(5,2.5$, and $1.25 \mathrm{mg} / \mathrm{mL})$ combined separately with $0.25 \mathrm{mg} / \mathrm{mL}$ AFE (Figure 3(a)).

Albendazole $(10 \mathrm{mg} / \mathrm{mL})$ killed all worms after $232.147 \pm$ $1.293 \mathrm{~min}$ of exposure. When $0.25 \mathrm{mg} / \mathrm{mL}$ AFE was combined with $10 \mathrm{mg} / \mathrm{mL}$ albendazole, it significantly $(p<0.0001)$ reduced the death time. Combination of $10 \mathrm{mg} / \mathrm{mL}$ albendazole with $0.25 \mathrm{mg} / \mathrm{mL}$ AFE killed the worms after $151.752 \pm$ $0.960 \mathrm{~min}$ of exposure. Similar effects were observed at lower concentrations of albendazole $(5,2.5$, and $1.25 \mathrm{mg} / \mathrm{mL})$ combined separately with $0.25 \mathrm{mg} / \mathrm{mL}$ AFE (Figure 3(b)).

Albendazole $(10 \mathrm{mg} / \mathrm{mL})$ paralyzed all worms after $130.721 \pm 1.499 \mathrm{~min}$ of exposure. When albendazole $(10 \mathrm{mg} / \mathrm{mL})$ was also combined with $0.125 \mathrm{mg} / \mathrm{mL}$ AFE, the worms were paralyzed after $119.712 \pm 0.713 \mathrm{~min}$ of exposure which showed significant $(p<0.01)$ reduction in paralysis time. Similar effects were observed when lower concentrations of albendazole ( 5 and $2.5 \mathrm{mg} / \mathrm{mL}$ ) were combined separately with $0.125 \mathrm{mg} / \mathrm{mL}$ AFE. Albendazole $(1.25 \mathrm{mg} / \mathrm{mL})$ paralyzed all worms after $357.7 \pm 2.975 \mathrm{~min}$ of exposure. 


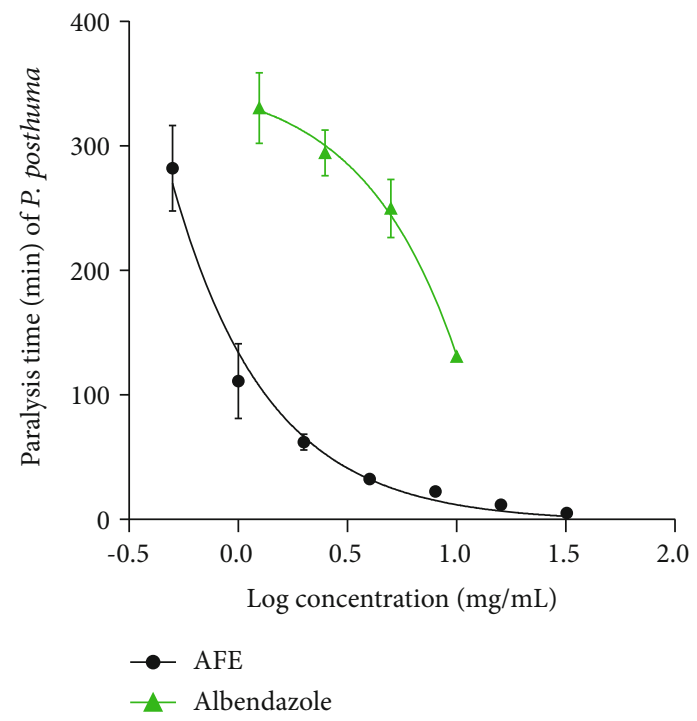

(a)

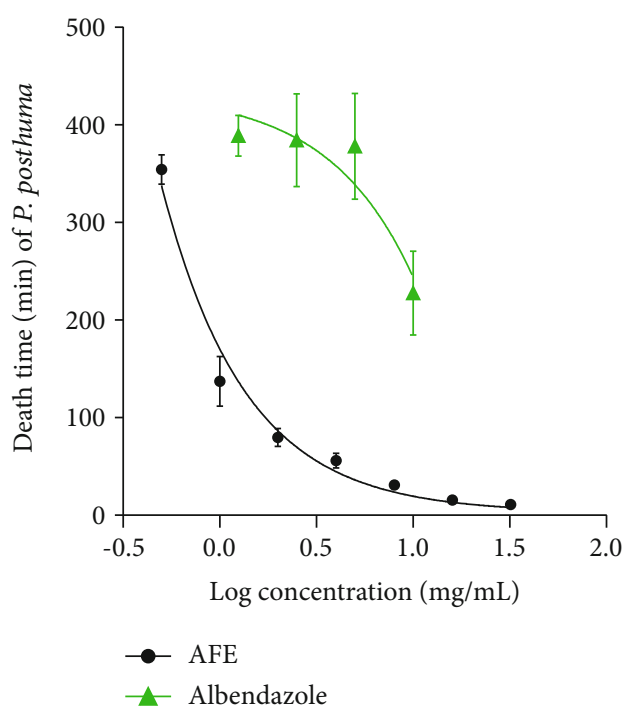

(b)

FIgURE 1: Effect of AFE and albendazole on paralysis and death of P. posthuma. (a) Paralysis time. (b) Death time. No paralysis and death was observed after the maximum time of exposure ( 8 hours) in the negative control group (Ringer's lactate solution). AFE: ethanol stem bark extract of $A$. ferruginea.

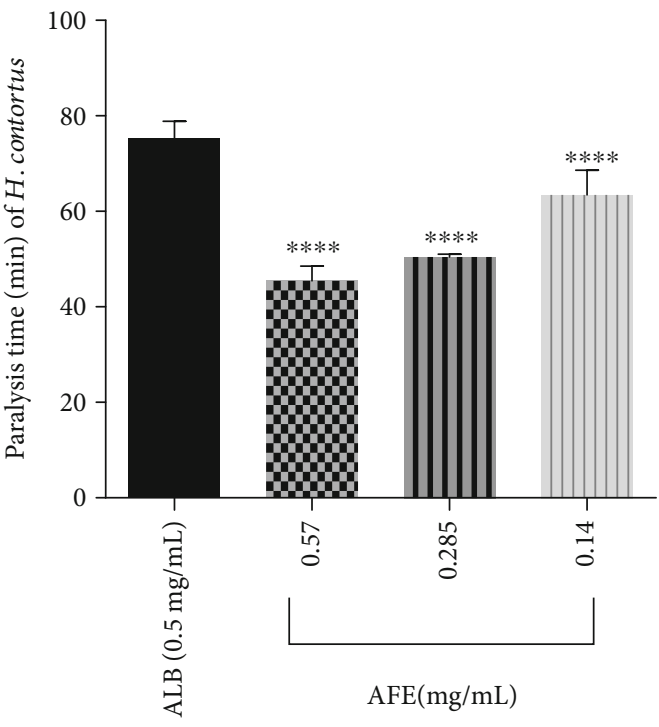

(a)

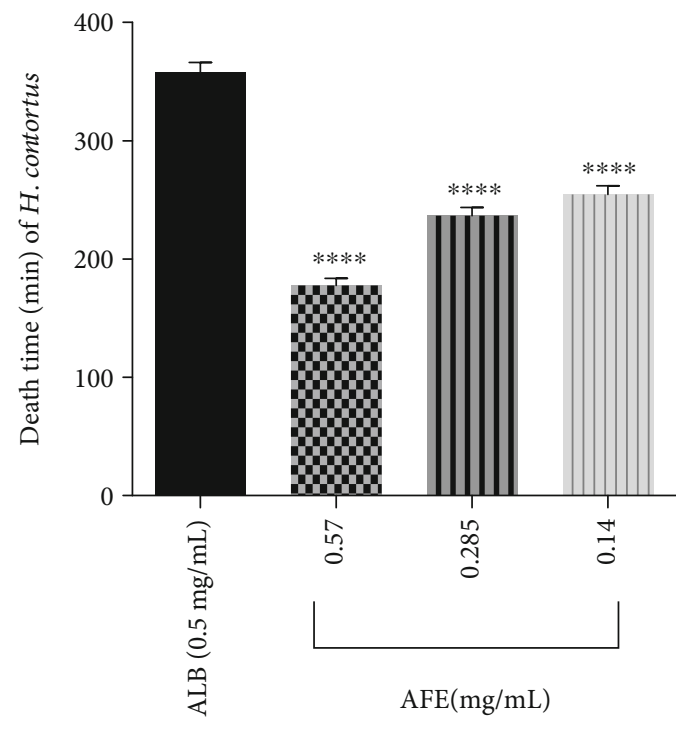

(b)

Figure 2: Effect of AFE on paralysis and death time of $H$. contortus. (a) Paralysis time. (b) Death time. ALB: albendazole; $n=9$, values are mean $\pm \mathrm{SEM} ;{ }^{* * *} p<0.0001$, compared to the control (one-way ANOVA followed by Dunnett's post hoc test). No paralysis was observed after maximum time of exposure ( 8 hours) in the negative control group (Ringer's lactate solution).

When $1.25 \mathrm{mg} / \mathrm{mL}$ albendazole was combined with $0.125 \mathrm{mg} / \mathrm{mL}$ AFE, paralysis time $(346.2 \pm 1.729 \mathrm{~min})$ was reduced as compared to albendazole $(1.25 \mathrm{mg} / \mathrm{mL})$ but this reduction in time was not significant (Figure $3(\mathrm{c})$ ).

Albendazole alone at $10 \mathrm{mg} / \mathrm{mL}$ killed all worms after $232.147 \pm 1.293 \mathrm{~min}$ of exposure. When $10 \mathrm{mg} / \mathrm{mL}$ albendazole was combined with $0.125 \mathrm{mg} / \mathrm{mL}$ AFE, the worms were killed after $224.954 \pm 1.164$ min of exposure, significantly $(p<0.0001)$ reducing the death time. Similar effects were observed at lower concentrations of albendazole $(5,2.5$, and
$1.25 \mathrm{mg} / \mathrm{mL}$ ) combined separately with $0.125 \mathrm{mg} / \mathrm{mL}$ AFE (Figure 3(d)).

3.5. Influence of AFE on Anthelmintic Activity of Mebendazole. Mebendazole alone at $10 \mathrm{mg} / \mathrm{mL}$ caused paralysis within $150.653 \pm 0.735 \mathrm{~min}$ of exposure. When combined with AFE $(0.25 \mathrm{mg} / \mathrm{mL})$, paralysis time increased to $157.288 \pm 0.572 \mathrm{~min}$ of exposure, significantly $(p<0.001)$ inhibiting the activity of mebendazole. Similar effects were observed when lower concentrations $(5,2.5,1.25$, and 


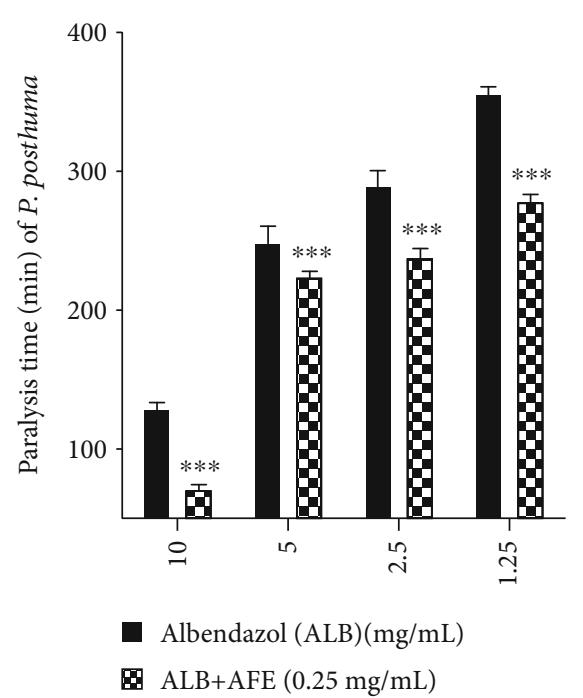

(a)

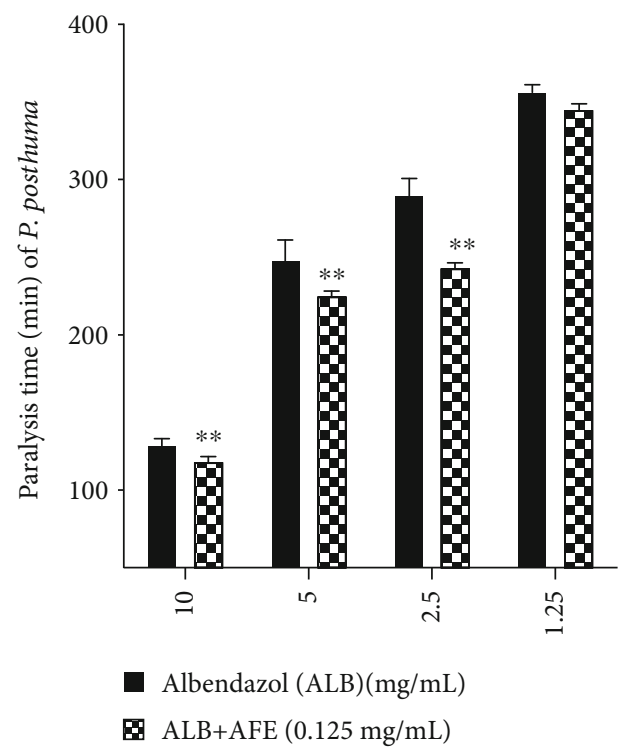

(c)

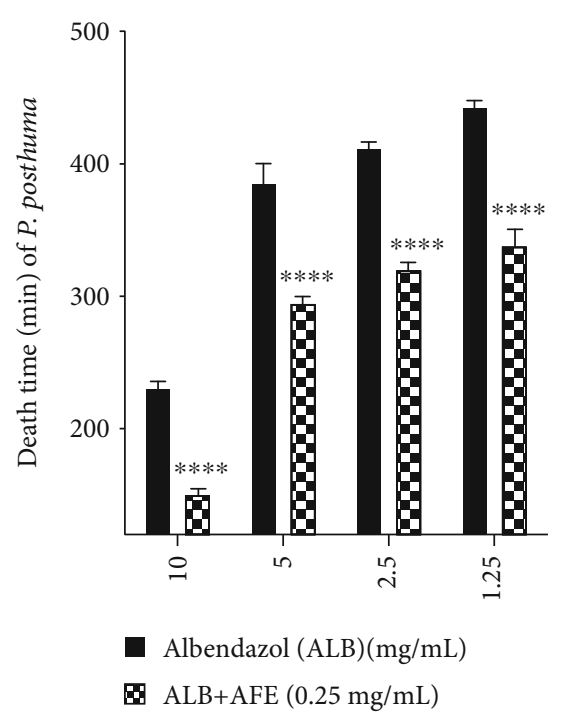

(b)

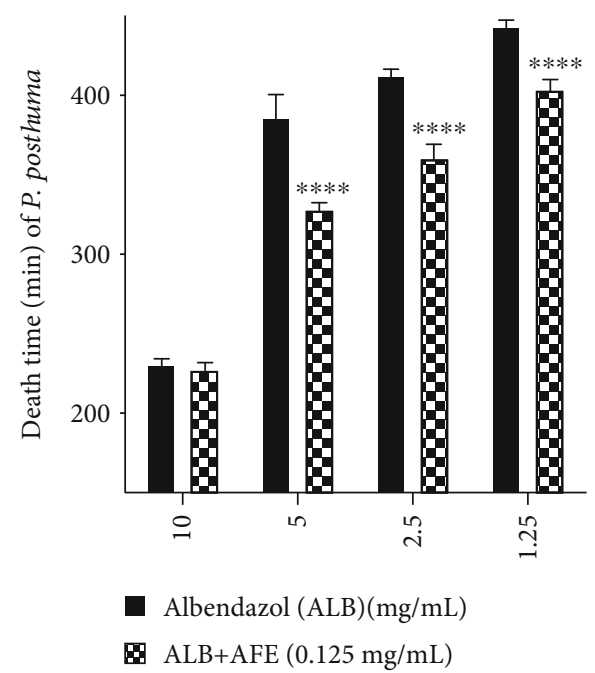

(d)

FIGURE 3: Effect of AFE on paralytic and helminthicidal activity of albendazole. (a, b) Effect of $0.25 \mathrm{mg} / \mathrm{mL}$ AFE on albendazole. (c, d) Effect of $0.125 \mathrm{mg} / \mathrm{mL}$ AFE on albendazole. ALB: albendazole; AFE: A. ferruginea ethanol stem bark extract; ${ }^{* * * *} p<0.0001,{ }^{* * *} p<0.001$, and ${ }^{* *} p<0.01$ compared to control (one-way ANOVA followed by Dunnett's post hoc test).

$0.625 \mathrm{mg} / \mathrm{mL}$ ) of mebendazole were combined with $0.25 \mathrm{mg} / \mathrm{mL}$ of AFE (Figure 4(a)).

Mebendazole alone at $10 \mathrm{mg} / \mathrm{mL}$ killed worms after $212.3967 \pm 0.974 \mathrm{~min}$ of exposure. When combined with AFE $(0.25 \mathrm{mg} / \mathrm{mL})$, the worms were killed after $260.963 \pm$ $0.981 \mathrm{~min}$ of exposure, thereby significantly $(p<0.0001)$ inhibiting the activity of mebendazole. Similar effects were observed when lower concentrations of mebendazole (5, $2.5,1.25$, and $0.625 \mathrm{mg} / \mathrm{mL}$ ) were combined with $0.25 \mathrm{mg} / \mathrm{mL}$ AFE extract Figure 4(b).

Mebendazole alone at $10 \mathrm{mg} / \mathrm{mL}$ caused paralysis within $150.653 \pm 0.735 \mathrm{~min}$ of exposure. Addition of AFE $(0.125 \mathrm{mg} / \mathrm{mL})$ caused paralysis after $298.273 \pm 1.157 \mathrm{~min}$ of exposure, thereby significantly $(p<0.0001)$ inhibiting the activity of mebendazole. Similar effects were observed when different concentrations of mebendazole $(5,2.5,1.25$, and $0.625 \mathrm{mg} / \mathrm{mL}$ ) were combined with $0.125 \mathrm{mg} / \mathrm{mL}$ AFE Figure 4(c).

Mebendazole alone at $10 \mathrm{mg} / \mathrm{mL}$ killed worms after $212.3967 \pm 0.974 \mathrm{~min}$ of exposure. When mebendazole $(10 \mathrm{mg} / \mathrm{mL})$ was combined with AFE $(0.125 \mathrm{mg} / \mathrm{mL})$, the worms were killed within $337.375 \pm 1.267 \mathrm{~min}$, significantly $(p<0.0001)$ inhibiting the activity of mebendazole. Similar effects were observed when lower concentrations of mebendazole $(5,2.5,1.25$, and $0.625 \mathrm{mg} / \mathrm{mL})$ were combined with $0.125 \mathrm{mg} / \mathrm{mL}$ AFE (Figure 4(d)).

3.6. Anthelmintic Activity of AFE Fractions against $P$. posthuma. All three fractions of AFE were active and expressed a concentration-dependent activity against $P$. 


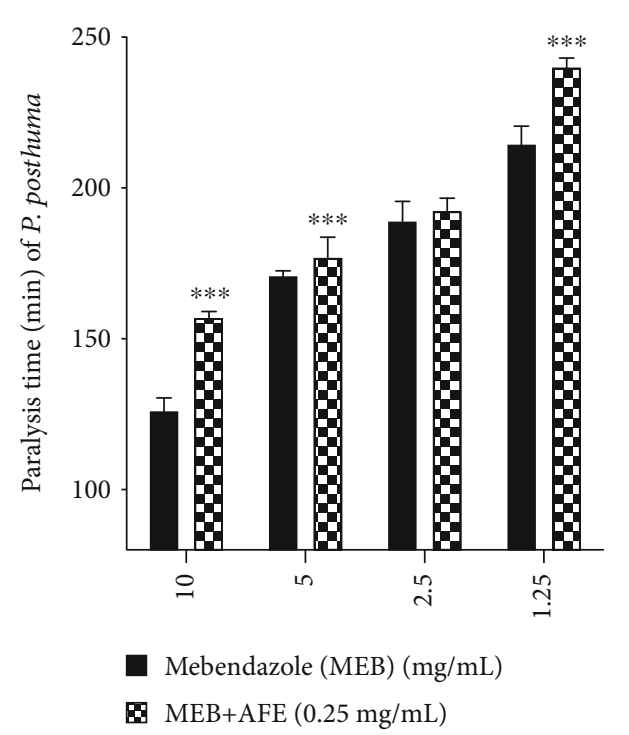

(a)

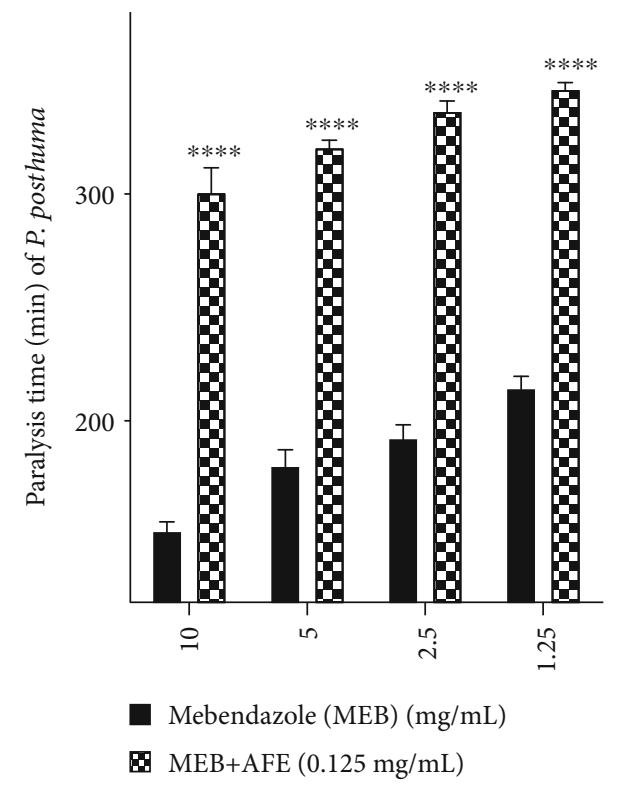

(c)

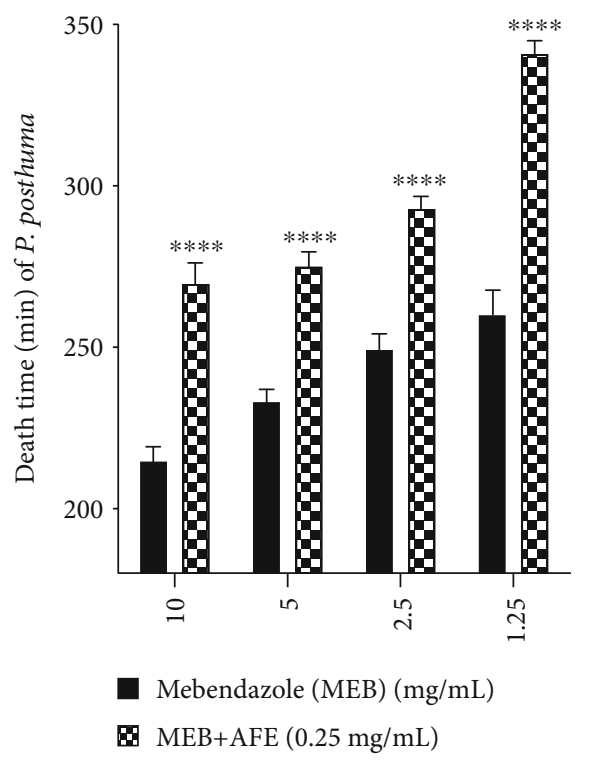

(b)

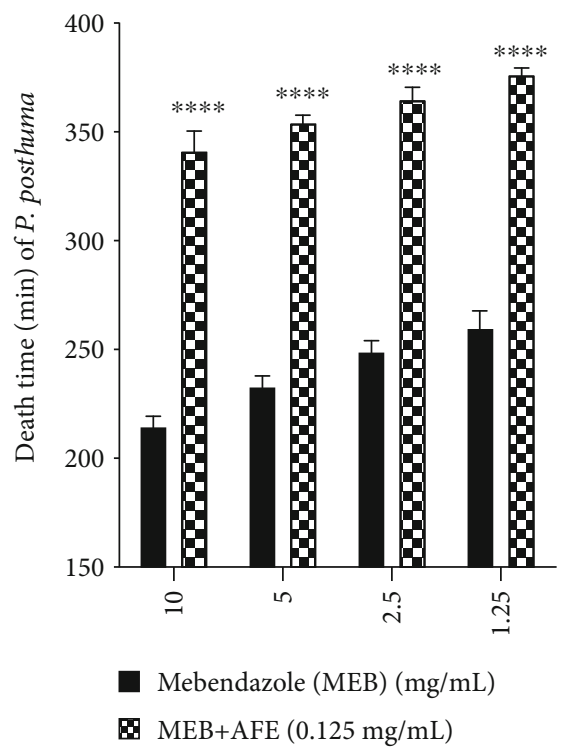

(d)

FIgURe 4: Effect of AFE on paralytic and helminthicidal activity of mebendazole. (a, b) Effect of $0.25 \mathrm{mg} / \mathrm{mL}$ AFE on mebendazole.(c, d) Effect of $0.125 \mathrm{mg} / \mathrm{mL}$ AFE on mebendazole. MEB: mebendazole; AFE: A. ferruginea ethanol stem bark extract; ${ }^{* * * *} p<0.0001,{ }^{* * *} p<0.001$ compared to the control (one-way ANOVA followed by Dunnett's post hoc test).

posthuma (Figure 5). The methanol fraction at its highest and lowest concentrations (32 and $0.5 \mathrm{mg} / \mathrm{mL}$ ) caused paralysis after $4.13 \pm 0.12$ and $69.90 \pm 0.15 \mathrm{~min}$, and death of worm after $4.13 \pm 0.12$ and $92.53 \pm 0.74 \mathrm{~min}$ of exposure, respectively (Figures 5(a) and 5(b)). The ethyl acetate fraction at its highest and lowest concentrations (32 and $0.5 \mathrm{mg} / \mathrm{mL}$ ) caused paralysis after $38.90 \pm 0.33$ and $264.24 \pm 2.90 \mathrm{~min}$, and death of worm after $25.25 \pm 1.52$ and $287.33 \pm 3.05 \mathrm{~min}$ of exposure, respectively (Figures 5(c) and 5(d)). The petroleum ether fraction at its highest and lowest concentrations (32 and $0.5 \mathrm{mg} / \mathrm{mL}$ ) caused paralysis after $24.60 \pm 0.40$ and $233.07 \pm 1.73 \mathrm{~min}$, and death of worm after $39.64 \pm 0.60$ and $413.53 \pm 0.774 \mathrm{~min}$ of exposure, respectively (Figures 5 (e) and $5(\mathrm{f}))$.

\section{Discussion}

Plants possess various medicinal properties due to the phytochemicals they produce during secondary vegetal metabolism $[31,32]$. In this study, the ethanol stem bark extract of A. ferruginea was found to contain tannins, saponins, glycosides, alkaloids, and coumarins (Table 1). This finding is in agreement with a report by Agyare et al. [18] who found that 


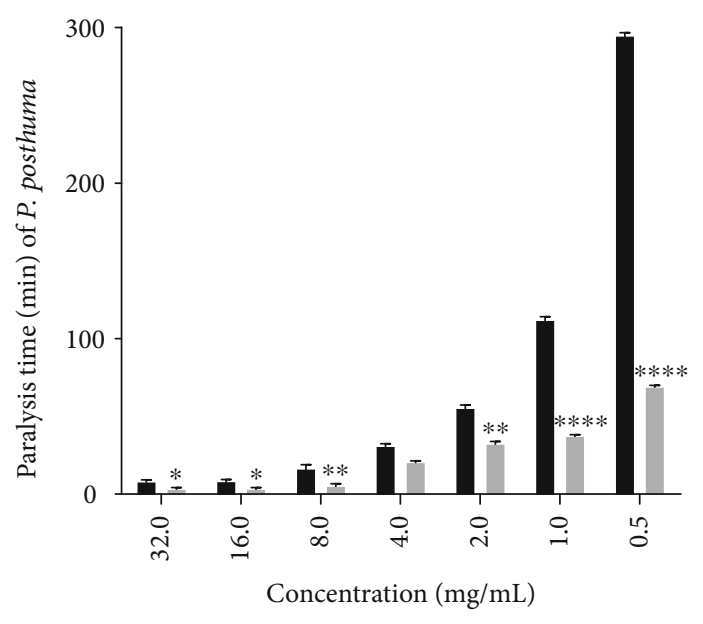

- AFE

- MEF

(a)

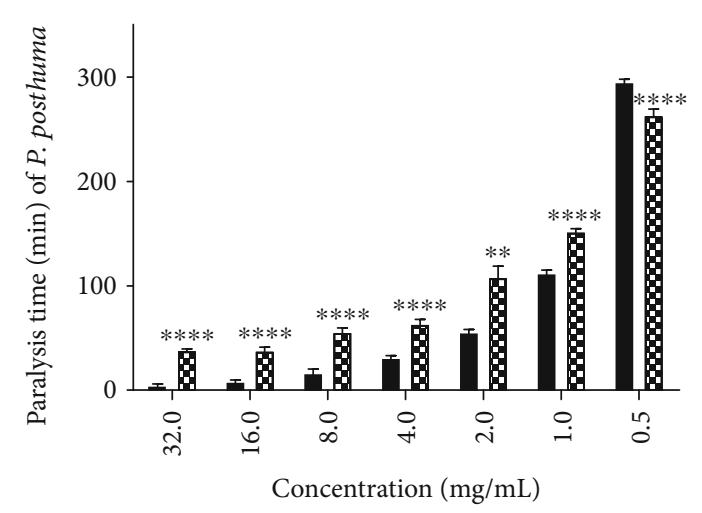

- AFE

D EAF

(c)

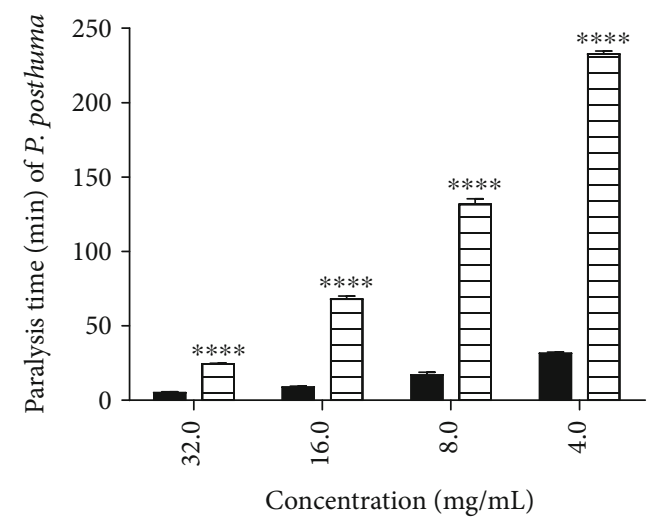

- AFE

目 $\mathrm{PEF}$

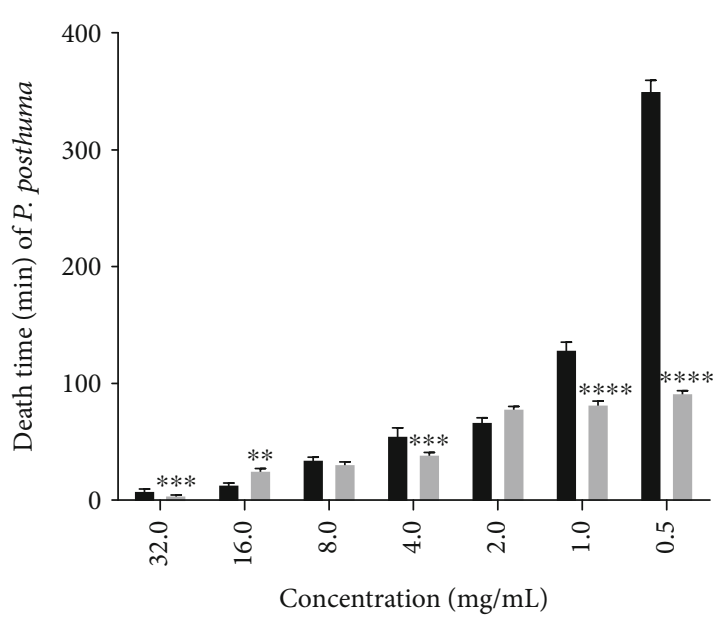

AFE

MEF

(b)

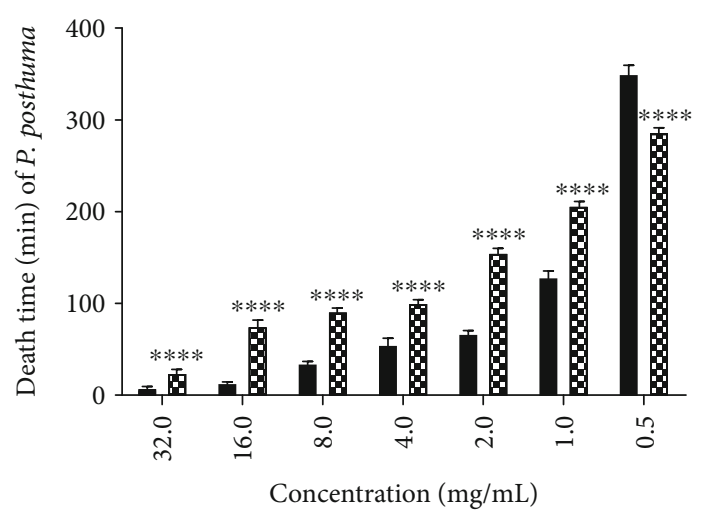

AFE

$\mathbf{E A F}$

(d)

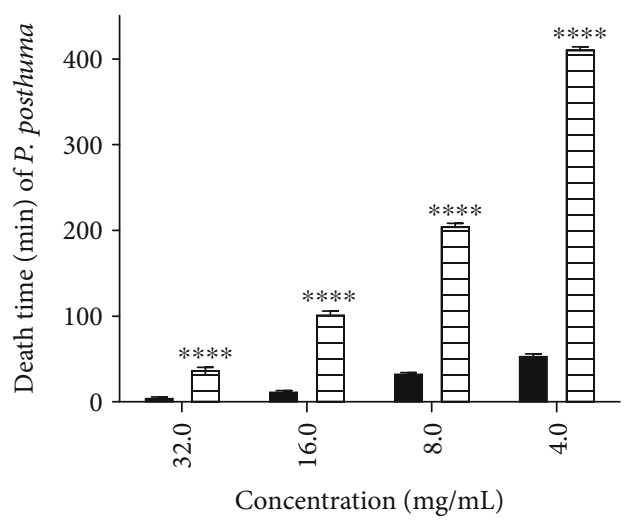

- $\mathrm{AFE}$

目 PEF

(e)

(f)

FIGURE 5: Comparison of the effect of AFE and its fractions (methanol, ethyl acetate, and petroleum ether fractions) on paralysis and death time of P. posthuma. (a, b) Paralysis and death time of methanol fraction, respectively. (c, d) Paralysis and death time of ethyl acetate fraction, respectively. (e, f) Paralysis and death time of petroleum ether fraction, respectively; ${ }^{* * * *} p<0.0001,{ }^{* * *} p<0.001,{ }^{* *} p<0.01$, and ${ }^{*} p<0.05$ compared to control (one-way ANOVA followed by Dunnett's post hoc test). AFE: A. ferruginea ethanol stem bark extract; MEF: methanol fraction of AFE; EAF: ethyl acetate fraction of AFE; PEF: petroleum ether fraction of AFE. 
the ethyl alcohol extract of leaves and stem bark of A. ferruginea contained tannins and saponins.

The anthelmintic activity of AFE (Figures 1 and 2) may be due to the presence of phytochemicals such as saponins, glycosides, and alkaloids. This is because it has been reported that secondary metabolites such as alkaloids and saponins possess anthelmintic activity [33-35]. Alkaloids which act as antioxidants reduce the generation of nitrate, which is known to interfere with local homeostasis which is necessary for helminth development [36]. Therefore, a reduction in nitrate generation by alkaloids in the extract probably may lead to the death of helminths.

Pheretima posthuma was used in this study due to its anatomic and physiological resemblance to the human intestinal roundworm, Ascaris lumbricoides [37]. Haemonchus contortus (strongylid nematode) which is a gastrointestinal parasitic nematode of small ruminants was also used because it is closely related to the human hookworm [38]. AFE showed dose-dependent paralytic and lethal effects on both $P$. posthuma and H. contortus (Figures 1 and 2). Studies have shown that a plant that exhibits anthelmintic activity against $P$. posthuma may show anthelmintic activity against $H$. contortus as well $[39,40]$. Since $H$. contortus is closely related to the human hookworm species, AFE may be active against the human hookworm as well [38]. Khan et al. (2010) reported that the methanol extract of Albizia lebbeck, an Albizia species, possesses anthelmintic activity against $H$. contortus. This supports the findings of this study and gives credence to the folkloric use of Albizia species as anthelmintics [19].

Plants have been known to enhance or inhibit the activity of known anthelmintic agents [30]. The anthelmintic activity of albendazole against $P$. posthuma was significantly $(p<0.0001, p<0.001$, and $p<0.01)$ enhanced in the presence of subactivity concentrations of AFE (Figure 3 ). This may involve enhanced disruption of the integrity of the helminth tegument, inhibition of motility, and reduction in glucose uptake by the worm [41] leading to the paralysis and eventually death of the worm. In a similar study [30], it was reported that the enhanced anthelmintic activity of albendazole may be due to the presence of secondary metabolites in the extract that increased drug uptake into the organism, making the drugs more available to the binding sites and eventually potentiating the activity of the anthelmintic drug.

AFE when combined with mebendazole significantly inhibited the paralytic and lethal activity of mebendazole (Figure 4). The exact mechanism of interaction between the drug and herb is not yet known [42]. However, some extracts may contain antagonistic compounds which may likely reduce the efficacy of a pharmaceutical drug $[43,44]$. It has been reported that some phytochemicals can form complexes with antimicrobial agents which can lead to reduced absorption, decreased affinity to the binding site, and subsequent loss of activity [45].

Seelinger et al. [46] observed that fractionation of plant extracts may lead to the isolation and separation of distinct desired properties of a plant. Methanol, ethyl acetate, and petroleum ether fractions of AFE were active against $P$. posthuma, and out of the three fractions, methanol fraction had a better anthelmintic activity (Figure 5). The methanol fraction also had better anthelmintic activity than the AFE (Figures 5(a) and 5(b)). Abu-Lafi et al. [47] reported that fractions may have better activity than whole extracts. The secondary metabolites present in A. ferruginea may be very polar since methanol is more polar than ethanol and most of the phytochemicals might have partitioned into it $[48,49]$. The AFE had better anthelmintic activity compared to the petroleum ether and ethyl acetate fractions. This could be due to the various secondary metabolites within the crude AFE that acted synergistically for its better anthelmintic activity [46].

\section{Conclusions}

The ethanol stem bark extract of A. ferruginea (AFE) possesses anthelmintic activity against $P$. posthuma and $H$. contortus. The methanol, ethyl acetate, and petroleum ether fractions of AFE also exhibited anthelmintic activity against $P$. posthuma. AFE significantly improved the paralytic and lethal effects of albendazole but inhibited the paralytic and lethal activity of mebendazole. Phytochemical screening performed on AFE revealed that it contains tannins, saponins, glycosides, alkaloids, and coumarins.

\section{Data Availability}

All data obtained from this study are within the manuscript.

\section{Conflicts of Interest}

The authors declare that there is no conflict of interest.

\section{Acknowledgments}

The authors are grateful to the laboratory technicians of the Faculty of Pharmacy and Pharmaceutical Sciences, particularly those of the Departments of Pharmaceutics (Microbiology Section).

\section{References}

[1] I. K. Idika, E. A. Okonkwo, D. N. Onah, I. O. Ezeh, C. N. Iheagwam, and C. O. Nwosu, "Efficacy of levamisole and ivermectin in the control of bovine parasitic gastroenteritis in the sub-humid savanna zone of southeastern Nigeria," Parasitology Research, vol. 111, no. 4, pp. 1683-1687, 2012.

[2] F. Samuel, "Status of soil-transmitted helminths infection in Ethiopia," American Journal of Health Research, vol. 3, no. 3, pp. 170-176, 2015.

[3] WHO, "Soil-transmitted helminth infections," 2018, 2019, http://www.who.int/news-room/fact-sheets/detail/soiltransmitted-helminth-infections.

[4] M. O. Harhay, J. Horton, and P. L. Olliaro, "Epidemiology and control of human gastrointestinal parasites in children," Expert Review of Anti-Infective Therapy, vol. 8, no. 2, pp. 219-234, 2010.

[5] S. Y. Gbedema and T. K. Gyampomah, "Accuracy of diagnosis of intestinal helminth parasites in a reference diagnostic laboratory in the Ashanti region of Ghana," International Journal of Parasitology Research, vol. 3, no. 1, pp. 12-16, 2011. 
[6] C. A. Danquah, G. A. Koffuor, K. Annan, and E. C. Ketor, "The anthelmintic activity of Vernonia amygdalina (Asteraceae) and Alstonia boonei De Wild (Apocynaceae)," Journal of Medical and Biomedical Sciences, vol. 1, no. 1, pp. 21-27, 2012.

[7] S. Kappagoda and J. P. Ioannidis, "Prevention and control of neglected tropical diseases: overview of randomized trials, systematic reviews and meta-analyses," Bulletin of the World Health Organization, vol. 92, no. 5, pp. 356-366C, 2014.

[8] V. Klauck, R. Pazinato, L. S. Lopes et al., “Trichostrongylus and Haemonchus anthelmintic resistance in naturally infected sheep from southern Brazil," Anais da Academia Brasileira de Ciências, vol. 86, no. 2, pp. 777-784, 2014.

[9] J. Praslicka, "Some aspects of the spread of anthelmintic resistance," Helminthologia, vol. 32, no. 1-2, pp. 75-77, 1995.

[10] H. A. Saddiqi, A. Jabbar, Z. Iqbal, W. Babar, Z. U. D. Sindhu, and R. Z. Abbas, "Comparitive efficacy of five anthelmintics against trichostrongylid nematodes in sheep," Canadian Journal of Animal Science, vol. 86, no. 4, pp. 471-477, 2006.

[11] K. Tripathi, Essentials of Medical Pharmacology, Jaypee Brothers Medical Publishers Ltd, New Delhi, 2013.

[12] A. Jabbar, M. A. Zaman, Z. Iqbal, M. Yaseen, and A. Shamim, "Anthelmintic activity of _Chenopodium album_(L.) and _Caesalpinia crista_(L.) against trichostrongylid nematodes of sheep," Journal of Ethnopharmacology, vol. 114, no. 1, pp. 86-91, 2007.

[13] H. A. Shalaby, "Anthelmintics resistance; how to overcome it?," Iranian Journal of Parasitology, vol. 8, no. 1, pp. 18-32, 2013.

[14] P. J. Waller, "International approaches to the concept of integrated control of nematode parasites of livestock," International Journal for Parasitology, vol. 29, no. 1, pp. 155-164, 1999.

[15] J. B. Githiori, J. Höglund, P. J. Waller, and R. L. Baker, "Evaluation of anthelmintic properties of some plants used as livestock dewormers against Haemonchus contortus infections in sheep," Parasitology, vol. 129, no. 2, pp. 245-253, 2004.

[16] K. Nazeerullah, K. Sunil, S. R. Pal, and D. Neelam, "A pharmacognostic and pharmacological overview on Caesalpinia bonducella," Research Journal of Pharmaceutical, Biological and Chemical Sciences, vol. 3, no. 1, pp. 440-496, 2012.

[17] P. A. Chander, H. Y. Sri, N. B. M. Sravanthi, and U. V. Susmitha, "In vitro anthelmintic activity of Barleria buxifolia on Indian adult earthworms and estimation of total flavonoid content," Asian Pacific Journal of Tropical Diseas, vol. 4, pp. S233-S235, 2014.

[18] A. Y. Mensah, C. Agyare, D. O. Agyemang, and G. A. Koffuor, "Antimicrobial and uterine smooth muscle activities of Albizia ferruginea extracts," Boletín Latinoamericano y del Caribe de Plantas Medicinales y Aromáticas, vol. 5, no. 2, pp. 144-147, 2006.

[19] K. Karuppannan, S. D. Priyadharshini, and S. Venugopal, "Phytopharmacological properties of Albizia species: a review," International Journal of Pharmacy and Pharmaceutical Sciences, vol. 5, Supplement 3, pp. 70-73, 2013.

[20] J. Kamga, L. P. Sandjo, N. Böke-Sarikahya, S. Kirmizigül, V. Kuete, and B. T. Ngadjui, "Albiziaflavane A: a new flavane from Albizia ferruginea (Mimosoideae)," Natural Product Research, vol. 28, no. 19, pp. 1574-1578, 2014.

[21] Y. N. Ditchou, C. A. Kombo, M. M. Opono, and B. Nyasse, "Antioxidant Activity of the Chemical Constituents Isolated from the Roots of Albizia ferruginea (Guill. and Perr.) Benth.
(Fabaceae)," Journal of Advanced Chemical Sciences, vol. 5, no. 3, pp. 646-651, 2019.

[22] B. N. Martin Thierry, M. G. Minoué Kuum, R. J. Temdie Guemmogne, J. C. Tchadji, A. Lissom, and T. Dimo, "Antiinflammatory effects of the stem barks from Albizia Ferruginea (Mimosaceae) on chronic inflammation induced in rats," International Journal of Innovative Research in Medical Scienc, vol. 3, no. 9, pp. 2183-2195, 2018.

[23] K. Twum-Ampofo, Albizia ferruginea (Guill. \& Perr.) Benth. Internet Record from PROTA4U, D. Louppe, A. A. OtengAmoako, and M. Brink, Eds., PROTA (Plant Resources of Tropical Africa / Ressources végétales de l'Afrique tropicale), Wageningen, Netherlands, 2007, 2019 https://www.prota4u .org/database/protav8.asp?g=pe\&p=Albizia+ferruginea $+($ Guill.+\&+Perr. $)+$ Benth.

[24] K. O. Akinyemi, O. Oladapo, C. E. Okwara, C. C. Ibe, and K. A. Fasure, "Screening of crude extracts of six medicinal plants used in South-West Nigerian unorthodox medicine for antimethicillin resistant Staphylococcus aureus activity," BMC Complementary and Alternative Medicine, vol. 5, no. 1, 2005.

[25] O. O. Aiyelaagbe and P. M. Osamudiamen, "Phytochemical screening for active compounds in Magnifera indica leaves from Ibadan," Plant Science Research, vol. 2, pp. 11-13, 2009.

[26] V. C. Mbatchou, D. P. Tchouassi, R. A. Dickson et al., "Mosquito larvicidal activity of Cassia tora seed extract and its key anthraquinones aurantio-obtusin and obtusin," Parasites \& Vectors, vol. 10, no. 1, 2017.

[27] A. Kumar B.S., K. Lakshman, K. N. Jayaveera, R. Nandeesh, B. Manoj, and D. Ranganayakulu, "Comparative in vitro anthelmintic activity of three plants from the Amaranthaceae family," Archives of Biological Sciences, vol. 62, no. 1, pp. 185-189, 2010.

[28] T. Eguale, G. Tilahun, A. Debella, A. Feleke, and E. Makonnen, "In vitro and in vivo anthelmintic activity of crude extracts of _Coriandrum sativum_ against_Haemonchus contortus_," Journal of Ethnopharmacology, vol. 110, no. 3, pp. 428-433, 2007.

[29] R. B. Besier, L. P. Kahn, N. D. Sargison, and J. A. van Wyk, "Diagnosis, Treatment and Management of Haemonchus contortus in Small Ruminants," Advances in Parasitology, vol. 93, pp. 181-238, 2016.

[30] F. Adu, C. Agyare, G. H. Sam, Y. D. Boakye, and V. E. Boamah, "Anthelmintic resistance modifying properties of extracts of Cyperus difformis L. (Cyperiaceae)," Investigational Medicinal Chemistry and Pharmacology, vol. 1, no. 1, pp. 1-12, 2018.

[31] M. al-Ansari, L. A. al-Humaid, P. Vijayaraghavan et al., "Identification of phytochemical components from Aerva lanata (Linn.) medicinal plants and its in-vitro inhibitory activity against drug resistant microbial pathogens and antioxidant properties," Saudi Journal of Biological Sciences, vol. 26, no. 6, pp. 1129-1133, 2019.

[32] N. Silva and A. Fernandes Júnior, "Biological properties of medicinal plants: a review of their antimicrobial activity," Journal of Venomous Animals and Toxins Including Tropical Diseases, vol. 16, no. 3, pp. 402-413, 2010.

[33] N. Ali, S. W. A. Shah, I. Shah, G. Ahmed, M. Ghias, and I. Khan, "Cytotoxic and anthelmintic potential of crude saponins isolated from Achillea Wilhelmsii C. Koch and Teucrium Stocksianum boiss," BMC Complementary and Alternative Medicine, vol. 11, no. 1, 2011.

[34] E. V. B. Azando, M. S. Hounzangbé-Adoté, P. A. Olounladé et al., "Involvement of tannins and flavonoids in the in vitro 
effects of Newbouldia laevis and Zanthoxylum zanthoxyloïdes extracts on the exsheathment of third-stage infective larvae of gastrointestinal nematodes," Veterinary Parasitology, vol. 180, no. 3-4, pp. 292-297, 2011.

[35] G.-X. Wang, Z. Zhou, D.-X. Jiang et al., "In vivo anthelmintic activity of five alkaloids from Macleaya microcarpa (Maxim) Fedde against Dactylogyrus intermedius in Carassius auratus," Veterinary Parasitology, vol. 171, no. 3-4, pp. 305-313, 2010.

[36] P. Jain, S. Singh, S. K. Singh, S. K. Verma, M. D. Kharya, and S. Solanki, "Anthelmintic potential of herbal drugs," International Journal of Research and Development in Pharmacy \& Life Sciences, vol. 2, no. 3, pp. 412-427, 2013.

[37] S. N. Basha, R. Rekha, S. Saleh, and S. Yemane, "Evaluation of Invitro anthelmintic activities of Brassica nigra, Ocimum basilicum and Rumex abyssinicus," Pharmacognosy Journal, vol. 3, no. 20, pp. 88-92, 2011.

[38] R. Laing, T. Kikuchi, A. Martinelli et al., "The genome and transcriptome of Haemonchus contortus, a key model parasite for drug and vaccine discovery," Genome biology, vol. 14, no. 8, 2013.

[39] R. Singh, A. Mehta, P. Mehta, and K. Shukla, "Anthelmintic activity of rhizome extracts of Curcuma Longa and Zingiber Officinale (Zingiberaceae)," International Journal of Pharmacy and Pharmaceutical Sciences, vol. 3, Supplement 2, pp. 11-12, 2011.

[40] Z. Iqbal, Q. K. Nadeem, M. N. Khan, M. S. Akhtar, and F. N. Waraich, "In vitro anthelmintic activity of Allium sativum, Zingiber officinale, Cucurbita mexicana and Ficus religiosa," International Journal of Agriculture and Biology, vol. 3, no. 4, pp. 454-457, 2001.

[41] E. T. Ryan, "Antiparasitic agents," in Principles and Practice of Pediatric Infectious Diseases, pp. 1567-1587.e2, Elsevier, 2018.

[42] N. Inamdar, S. Edalat, V. Kotwal, and S. Pawar, "Herbal drugs in milieu of modern drugs," International Journal of Green Pharmacy, vol. 2, no. 1, p. 2, 2008.

[43] X.-W. Chen, K. B. Sneed, S.-Y. Pan et al., "Herb-drug interactions and mechanistic and clinical considerations," Current Drug Metabolism, vol. 13, no. 5, pp. 640-651, 2012.

[44] S. P. Borse, D. P. Singh, and M. Nivsarkar, "Understanding the relevance of herb-drug interaction studies with special focus on interplays: a prerequisite for integrative medicine," Porto Biomedical Journal, vol. 4, no. 2, 2019.

[45] A. Francis, A. A. John, K. Noble, G. A. William, A. Theresa, and N. M. David, "Antimicrobial and antioxidant activities of Citrus sinensis var. late Valencia fruits at various stages of development," African Journal of Microbiology Research, vol. 10, no. 3, pp. 73-78, 2016.

[46] M. Seelinger, R. Popescu, P. Seephonkai et al., "Fractionation of an extract of Pluchea odorata separates a property indicative for the induction of cell plasticity from one that inhibits a neoplastic phenotype," Evidence-Based Complementary and Alternative Medicine, vol. 2012, Article ID 701927, 11 pages, 2012.

[47] S. A. Abu-Lafi, M. Akkawi, Q. Abu-Remeleh, S. Jaber, M. Qutob, and P. Lutgen, "Pure isolates and preparative HPLC fractions or crude extract of Inula viscosa: effect on $\beta$-hematin inhibition in vitro," Pharmacy \& Pharmacology International Journal, vol. 6, no. 1, 2018.
[48] K. K. Waltrich, J. Hoscheid, and I. S. Prochnau, “Antimicrobial activity of crude extracts and fractions of Vernonia polyanthes Less (assa-peixe) flowers," Revista Brasileira de Plantas Medicinais, vol. 17, no. 4, Supplement 2, pp. 909-914, 2015.

[49] S. B. Iloki-Assanga, L. M. Lewis-Luján, C. L. Lara-Espinoza et al., "Solvent effects on phytochemical constituent profiles and antioxidant activities, using four different extraction formulations for analysis of Bucida buceras L. and Phoradendron californicum," BMC Research Notes, vol. 8, no. 1, 2015. 